\title{
Protective Effect of a Synthetic Antioxidant "Acetyl Gallate Derivative” Against Dimethoate Induced DNA Damage and Oxidant/Antioxidant Status in Male Rats
}

\author{
Tarek M. Heikal'* , Abdel-Tawab H. Mossa1, Galal A. M. Nawwar ${ }^{2}$, Mahmoud El-Sherbiny ${ }^{3}$ and Hassan Z. Ghanem ${ }^{3}$
}

${ }^{1}$ Pesticide Chemistry Department, National Research Centre, Cairo, Egypt

${ }^{2}$ Green Chemistry Department, National Research Centre, Cairo, Egypt

${ }^{3}$ Therapeutic Chemistry Department, National Research Centre, Cairo, Egypt

\begin{abstract}
The present study was conducted to investigate the protective effects of a synthetic antioxidant "acetyl gallate derivative" (SAC) against hepatic oxidative stress and brain DNA damage induced by dimethoate (DM) in male rats. DM was orally administrated to the rats at a dose of $38.7 \mathrm{mg} \mathrm{kg}^{-1} \mathrm{~b}$.wt. $\left(1 / 10 \mathrm{LD}_{50}\right)$, for 28 consecutive days. Additional DM groups received either SAC or vitamin C (VC) at a dose of $200 \mathrm{mg} \mathrm{kg}^{-1} \mathrm{~b}$.wt. 30 min before DM administration. Compared to the control, DM induced a statistical reduction in body weight gain, while induced a statistical increase in absolute and relative liver weights. Oral administration of DM significantly caused increases in hepatic lipid peroxidation (LPO) and activities of antioxidant enzymes including catalase (CAT), superoxide dismutase (SOD) and glutathione-s-transferease (GST), while caused decreases in glutathione content (GSH) and serum cholinesterase (ChE) activity. Administration of SAC attenuates LPO, GSH content and antioxidant enzymes system. The severity of brain DNA damage monitored by damage index (DI) and damage frequency \% (DF) induced by DM was mitigated after administration of SAC. In conclusion, supplementation of SAC is more reliable than VC in attenuating relative liver weight, SOD, GST, and brain DNA damage.
\end{abstract}

Keywords: Antioxidant enzymes; Dimethoate; DNA damage; Acetyl gallate derivative; Oxidative stress

\section{Introduction}

Pesticides are occasionally used indiscriminately in large amounts causing environmental pollution and potential health hazards. Organophosphate pesticides (OP) are primarily recongnized for their ability to induce toxicity in mammals through inhibition of acethylcholinesterase (AChE) [1]. Also, it has been demonstrated that lipid peroxidation mediated by free radicals is one of the molecular mechanisms involved in OP-induced toxicity $[2,3]$ and several pesticides exert their biological effects through electrophilic attack on the cellular constituents of hepatic and brain tissues [4] with simultaneous generation of reactive oxygen species [5]. In this regard, several studies have proved oxidative stress is induced by OP in rats $[2,3,6-8]$ and in humans [9].

Dimethoate, DM, (O, O-dimethyl S-N-methyl carbamoyl methyl phosphorodithioate) is widely used against a broad range of insects and mites and is also used for indoor control of houseflies. The extensive use of DM poses a health hazard to animals and humans because of its persistence in soil and crops [10]. Previous studies have shown that acute and sub-chronic exposure to DM alters the antioxidant status and the histology of liver and induce hepatic lipid peroxidation in mice [11] and rats [2,12-14].

Antioxidants as vitamins, can prevent the uncontrolled formation of free radicals or inhibit their reaction with biological sites, also the destruction of most free radicals rely on the oxidation of endogenous antioxidants mainly by scavenging and reducing molecules [15]. Vitamin C (VC), as a water soluble antioxidant is reported to neutralize reactive oxygen species (ROS) and reduce oxidative DNA damage and hence genetic mutations $[16,17]$. In our laboratory, newly synthesized compounds utilizing acetyl gallate derivatives (SAC) have been tested in vitro as antioxidants [18]. The 2-Cyano-N-[1-(2', 3', 4'-trimethoxyphenyl)ethylidene]acetohydrazide (Figure 1) showed an interesting antioxidant activity and absence of mortality of rats received $5000 \mathrm{mg} \mathrm{kg}^{-1}$ b.wt. of this compound rationale further in vivo study. Therefore, the objectives of this study was conducted to investigate the protective effects of a synthetic antioxidant acetyl gallate derivative (SAC) against hepatic oxidative stress and brain DNA damage induced by $\mathrm{DM}$ in male rats.

\section{Materials and Methods}

\section{Animals}

Healthy male Wister rats weighing $160 \pm 10 \mathrm{~g}$ were obtained from the Animal Breeding House of the National Research Centre (NRC), Dokki, Cairo, Egypt, and maintained in clean plastic cages in the laboratory animal room $\left(23 \pm 2^{\circ} \mathrm{C}\right)$. On standard pellet diet, tap water ad libitum, and daily dark/light cycle (12/12 hrs.) the rats were acclimatized for 1 week prior to the start of experiments. The experimental work on rats was performed with the approval of the Animal Care \& Experimental Committee, National Research Centre, Cairo, Egypt, and international guidelines for care and use of laboratory animals.

*Corresponding author: Tarek M. Heikal, Environmental Toxicology Research Unit (ETRU), Pesticide Chemistry Department, National Research Centre, Tahrir Street, P.O. Box 12311, Dokki, Cairo, Egypt; Tel: 202-33371211-33371615; Fax: 202-33370931; E-mail: tarekhl@yahoo.com

Received July 02, 2012; Accepted September 13, 2012; Published Septembe 18, 2012

Citation: Heikal TM, Mossa ATH, Nawwar GAM, El-Sherbiny M, Ghanem HZ (2012) Protective Effect of a Synthetic Antioxidant "Acetyl Gallate Derivative Against Dimethoate Induced DNA Damage and Oxidant/Antioxidant Status in Male Rats. J Environ Anal Toxicol 2:155. doi:10.4172/2161-0525.1000155

Copyright: @ 2012 Heikal TM, et al. This is an open-access article distributed unde the terms of the Creative Commons Attribution License, which permits unrestricted use, distribution, and reproduction in any medium, provided the original author and source are credited. 
Citation: Heikal TM, Mossa ATH, Nawwar GAM, El-Sherbiny M, Ghanem HZ (2012) Protective Effect of a Synthetic Antioxidant "Acetyl Gallate Derivative" Against Dimethoate Induced DNA Damage and Oxidant/Antioxidant Status in Male Rats. J Environ Anal Toxicol 2:155. doi:10.4172/2161-0525.1000155

Page 2 of 7<smiles>C/C(=N\NC(=O)CC#N)c1ccc(O)c(O)c1O</smiles>

Figure 1: 2-Cyano-N-[1-(2', 3', 4'-trimethoxyphenyl)ethylidene]acetohydrazide.

\section{Chemicals}

Dimethoate (Perfekthion 40\% EC, BASF, Germany) and Vitamin C (L-Ascorbic acid) were purchased from Sigma-Aldrich Chemie (Steinheim, Germany). Kits used for biochemical measurements were purchased from Biodiagnostic, Giza, Egypt. All other chemicals were of reagent grades and were obtained from the local scientific distributors in Egypt.

Synthesis of 2-Cyano-N-[1-(2, 3, 4-trimethoxyphenyl) ethylidene] acetohydrazide

The antioxidant compound used in the experiment was prepared in our laboratory according to El-Ebiary et al. [18].

\section{Animal treatment schedule}

Rats were randomly divided into 6 groups each containing 6 animals ( 6 rats/cage). The route of administration selected for the study was daily oral gavage for 28 consecutive days. Rats in Group I served as control and were given DMSO (0.5 ml/rat). Rats in Group II (VC) were given vitamin $\mathrm{C}$ in water at a dose of $200 \mathrm{mg} / \mathrm{kg}$ b.wt. $(0.5 \mathrm{ml} /$ rat). Rats in Group III (SAC) were administered SAC in DMSO at a dose of $200 \mathrm{mg} \mathrm{kg}^{-1}$ b.wt. Rats in Group IV (DM) were administered dimethoate in water at a dose of $38.7 \mathrm{mg} \mathrm{kg}^{-1}$ b.wt. $\left(1 / 10 \mathrm{LD}_{50}\right)$ Tomlin [19]. Rats in Group V (DM+VC) and VI (DM+SAC) were given the same doses of VC and SAC as in groups II and III $30 \mathrm{~min}$ before the administration of DM (38.7 $\mathrm{mg} \mathrm{kg}^{-1}$ b.wt.), respectively. During the experimental duration, body weights were weekly recorded and the doses of the tested compounds were modulated accordingly.

The selected dose of vitamin C (200 $\mathrm{mg} \mathrm{kg}^{-1} \mathrm{~b}$.wt) was cited from previous investigators [20,21], whereas, the dose of DM used in this study $\left(1 / 10\right.$ of $\left.\mathrm{LD}_{50}\right)$ was adopted by many previous investigators, since it is toxic but not lethal to rats $[12,22]$.

\section{Data recording and sample collection}

After completion of treatment period, body weights were recorded. Blood samples were withdrawn from the animals under light ether anesthesia by puncturing the retro-orbital venous plexus of the animals with a fine sterilized glass capillary tube. The collected blood samples were left for 20 minutes to coagulate at room temperature, and then centrifuged at $600 \mathrm{x}$ g for $10 \mathrm{~min}$ to separate the sera. The sera were kept for one week in a deep freezer $\left(-20^{\circ} \mathrm{C}\right)$ until analyzed.

The rats were sacrificed by cervical dislocation. Immediately, brain tissues were cryopreserverd at $-80^{\circ} \mathrm{C}$ in RPMI 1640 media (w/o L-Glutamine, w/ 25 mM Hepes) (biowest) Containing 10\% DMSO and 1\% Fetal Calf Serum, until processing for comet assay. Liver tissues were isolated, cleaned from of adhering matters, washed with icecold saline solution, weighed and stored at $-70^{\circ} \mathrm{C}$ for the biochemical studies.

\section{Biochemical measurements}

The sera and liver homogenates obtained from different treatments were stored and subjected to certain biochemical analyses by using Shimadzu UV-VIS Recording 2401 PC (Japan).

Lipid peroxidation (LPO) and glutathione (GSH): Liver tissues were separately homogenized in ice-cold $50 \mathrm{mM}$ phosphate buffer ( $\mathrm{pH} 7.5,1 \mathrm{mM}$ EDTA) for $2 \mathrm{~min}$ to yield a $10 \%$ (w/v) homogenates, using a Teflon-fitted Potter Elvehjem homogenizer. The homogenates were centrifuged at $800 \mathrm{xg}$ at $4^{\circ} \mathrm{C}$ for $15 \mathrm{~min}$. The supernatants were immediately collected and used for the quantification of LPO and GSH according to the method of Ohkawa et al. [23] and Owens and Belcher [24], respectively. LPO was determined based on the formation of thiobabituric acid reactive substances (TBARS) at $532 \mathrm{~nm}$ and expressed as the extent of malondialdehyde (MDA) production. GSH is based on the reaction of DTNB [5, 5- dithiobis-(2-nitrobenzoic acid)] with GSH and yield a yellow colored chromophore; 5 -thio-nitrobenzoic acid with a maximum absorbance at $412 \mathrm{~nm}$.

Antioxidant enzymes: Another part of liver tissues were separately homogenized in ice-cold $50 \mathrm{mM}$ phosphate buffer $(\mathrm{pH} 7.4,1 \mathrm{mM}$ EDTA and $1 \mathrm{~mL} / \mathrm{L}$ Triton X-100) for 2 min to yield a $10 \%(\mathrm{w} / \mathrm{v})$ homogenates. The homogenates were centrifuged at $800 \mathrm{x}$ g at $4^{\circ} \mathrm{C}$ for $15 \mathrm{~min}$. The supernatants were immediately used for assaying catalase (CAT) activity by the method of Aebi [25]. The activity of CAT was expressed as nmoles $\mathrm{min}^{-1} \mathrm{mg}^{-1}$ protein and the change in absorbance was measured at $510 \mathrm{~nm}$.

Parts of liver tissues were separately homogenized in ice-cold $0.25 \mathrm{M}$ sucrose for $2 \mathrm{~min}$ to yield a $10 \%(\mathrm{w} / \mathrm{v})$ homogenates. The homogenates were centrifuged at $800 \mathrm{x} \mathrm{g}$ at $4^{\circ} \mathrm{C}$ for $15 \mathrm{~min}$. The supernatants were immediately used for assaying superoxide dismutase (SOD) activity by the method of Nishikimi et al. [26]. The activity of SOD was expressed as units of SOD $\mathrm{min}^{-1} \mathrm{mg}^{-1}$ protein and the change in absorbance was measured at $560 \mathrm{~nm}$.

Glutathione-S-transferase (GST) activity was assayed by the method of Habig et al. in $0.1 \mathrm{M}$ phosphate buffer $(\mathrm{pH} 7.0,2 \mathrm{mM}$ EDTA) [27]. The activity was expressed as $\mu \mathrm{mol}$ of 1-chloro-2, 4-dinitrobenzene (CDNB)-GSH conjugate $\mathrm{min}^{-1} \mathrm{mg}^{-1}$ protein and the change in absorbance at $340 \mathrm{~nm}$ was monitored in a UV-visible spectrophotometer.

Total protein and Cholinesterase (CHE): The protein concentrations were measured as described by Lowry et al. in liver homogenate [28]. Cholinesterase (ChE; EC 3.1.1.8) activity was determined in the sera according to the method described by Ellman et al. [29].

\section{DNA damage analysis}

The alkaline comet assay (or single cell gel electrophoresis-SCGE) was carried out as described by Singh et al. and Tice et al. [30,31]. Prealiquot cyropreserved brain cells were thawed in water bath at $37^{\circ} \mathrm{C}$, wash with phosphate-buffered saline (PBS) containing $20 \mathrm{mM}$ EDTA $\left(\mathrm{Ca}^{2+}\right.$ and $\mathrm{Mg}^{2+}$ free), then weigh. Each piece of $0.2 \mathrm{~g}$ of cerebral cortex of brain tissue was placed in $1 \mathrm{ml}$ of cold PBS phosphate-buffered saline containing $20 \mathrm{mM}$ EDTA $\left(\mathrm{Ca}^{2+}\right.$ and $\mathrm{Mg}^{2+}$ free) and minced into fine pieces in order to obtain a cellular suspension. These cells from brain (10 $\mu \mathrm{l})$ were embedded in $95 \mu \mathrm{l}$ of $0.75 \%$ low melting agarose (Gibco-BRL). 
Citation: Heikal TM, Mossa ATH, Nawwar GAM, El-Sherbiny M, Ghanem HZ (2012) Protective Effect of a Synthetic Antioxidant "Acetyl Gallate Derivative" Against Dimethoate Induced DNA Damage and Oxidant/Antioxidant Status in Male Rats. J Environ Anal Toxicol 2:155. doi:10.4172/2161-0525.1000155

Page 3 of 7

The mixture (cell/agarose) was added to a fully frosted microscope slide coated with a layer of $300 \mu \mathrm{l}$ of normal melting agarose (1\%) (Gibco$\mathrm{BRL})$. After solidification, the slides were placed in lysis buffer $(2.5 \mathrm{M}$ $\mathrm{NaCl}, 100 \mathrm{mM}$ EDTA and $10 \mathrm{mM}$ Tris, $\mathrm{pH}$ 10.0, with freshly added $1 \%$ Triton X-100 (Sigma) and 10\% DMSO) for one h at $4^{\circ} \mathrm{C}$. Subsequently, the slides were incubated in freshly made alkaline buffer $(300 \mathrm{mM}$ $\mathrm{NaOH}$ and $1 \mathrm{mM}$ EDTA, $\mathrm{pH}>13$ ) for $20 \mathrm{~min}$, at $4^{\circ} \mathrm{C}$ to allow DNA to unwind. An electric current of $300 \mathrm{~mA}$ and $25 \mathrm{~V}(0.90 \mathrm{~V} / \mathrm{cm})$ was applied for $15 \mathrm{~min}$ to electrophoreses the DNA. After electrophoresis, the slides were placed in a staining tray and covered with neutralizing solution (0.4M Tris, $\mathrm{pH} 7.5)$ for $5 \mathrm{~min}$ and washed three times. The slides were drained and $50 \mu \mathrm{l}$ of ethidium bromide solution $(20 \mu \mathrm{g} \mathrm{ml}$ $\left.{ }^{1}\right)$ (Sigma) were added. Slides were placed in a humid dark box at $4^{\circ} \mathrm{C}$ until analysis, which was done immediately.

The presence of comets was examined in cells using Leica epifluorescent microscope (Green filter), the images for the brain cell nucleoids were digitalized with Leica DFC camera. DFC 280 supplied with Leica DFC Twain software with Host application program Imaging to view and capture digital images.

Scoring of the slide was done visually according to tail size into five classes $(0,1,2,3,4)$ ranging from undamaged (class 0$)$ to maximum damage (class 4) (Figure 2), resulting in a single DNA damage score for each animal, and consequently each studied group. Coded slides were scored blindly and 100 brain cell nucleoids were scored from each animal ( 50 per slide). Therefore, the composite score (damage index) can range from 0 (completely undamaged, 100 cells $\mathrm{x} 0$ ) to 400 (with maximum damage, 100x4) as described by Collins et al. [32]. The damage frequency (\%) was calculated based on a number of cells with tail versus those with no tails.

\section{Statistical analysis}

The results were expressed as means \pm standard deviation. All data were done with the Statistical Package for Social Sciences (SPSS 11.0 for windows). The results were analyzed using one way analysis of variance (ANOVA) followed by Duncan's test for comparison between different treatment groups. Statistical significance was set at $\mathrm{p}<0.05$.

\section{Results}

\section{The effects of DM on general rat health}

Generally, no death was observed in any of the experimental groups during the treatment period (28 days). However, few clinical signs such as huddling, reduced activity and hair loss were observed in DM-treated rats. The observed signs were related to the cholinergic syndromes. However, except of huddling, no other clinical manifestation was observed following either VC or SAC supplementation.

\section{Body and organ weights}

At the end of the experimental period, body weight gain, absolute and relative liver weights did not significantly differ in VC-treated and SAC-treated groups compared to the control group (Table 2). However, there was a statistically significant decrease in the body weight gain and a significant increase in the relative liver weights when DM and $\mathrm{DM}+\mathrm{VC}$-treated groups compared to the control group.

\section{Cholinesterase activity (ChE)}

Compared to control value, the activity of ChE was inhibited, by $32 \%$, in the sera of rats administered DM (Figure 3). This inhibition was attenuated by $13.75 \%$ in VC supplementation and by $10.44 \%$ in SAC supplementation.

\section{Lipid peroxidation and glutathione (LPO \& GSH)}

In DM-treated group, LPO in hepatic tissue was increased significantly (Figure 4), while GSH content was decreased significantly (Figure 5), when compared to the control group. However, supplementation of either VC or SAC attenuated the significant changes in both LPO and GSH content. Further, SAC treatment, by itself, boosted GSH content in the liver tissue. VC was more effective than SAC in attenuating the hepatic LPO.

\section{Antioxidant enzymes}

Data on the activities of various hepatic antioxidant enzymes following $\mathrm{DM}, \mathrm{VC}$, and SAC treatments is presented in table 2. The activities of CAT, SOD and GST enzymes were significantly

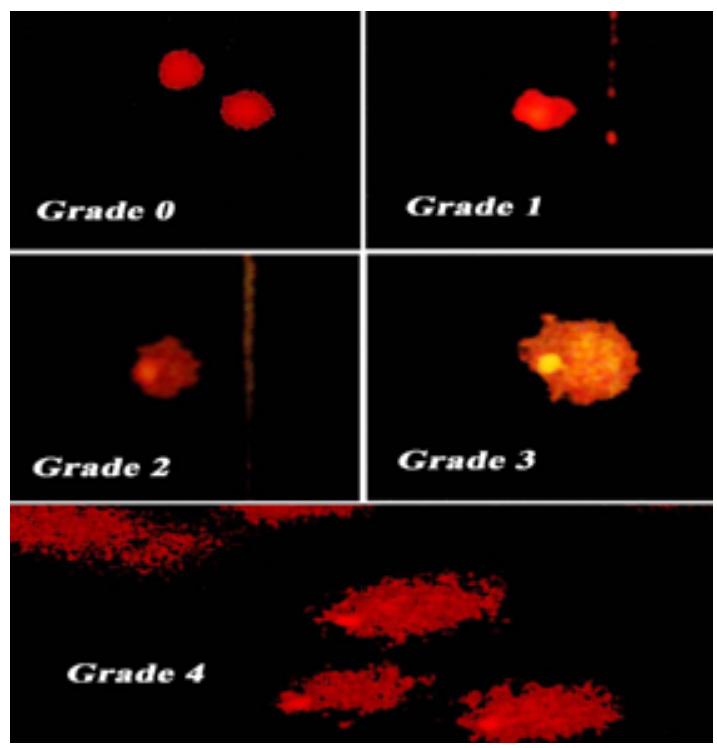

Figure 2: Representative images of the comet assay grades according to tail size, from no tail (Grade 0), to maximally long tail (Grade 4).

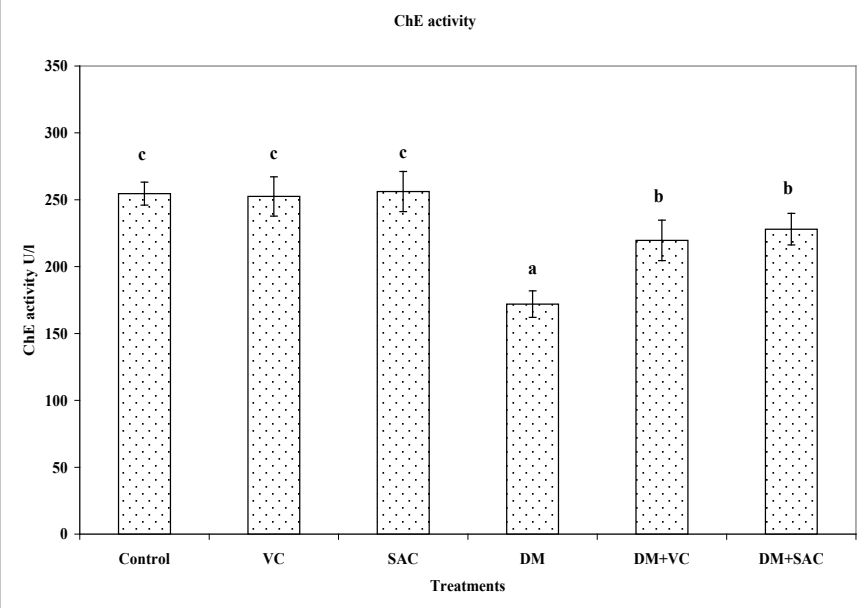

Figure 3: Effect of repetitive doses, for 28 consecutive days, of DM and different antioxidants on ChE activity in sera of rat. Values are expressed as mean \pm S.D. of 6 rats; ${ }^{a, b, c}$ values are not sharing superscripts letters $(a, b$ c,) differ significantly at $p<0.05$; ChE: cholinesterase; DM: dimethoate; VC: vitamin C; SAC: synthetic antioxidant compound. 
Citation: Heikal TM, Mossa ATH, Nawwar GAM, El-Sherbiny M, Ghanem HZ (2012) Protective Effect of a Synthetic Antioxidant "Acetyl Gallate Derivative" Against Dimethoate Induced DNA Damage and Oxidant/Antioxidant Status in Male Rats. J Environ Anal Toxicol 2:155. doi:10.4172/2161-0525.1000155

Page 4 of 7

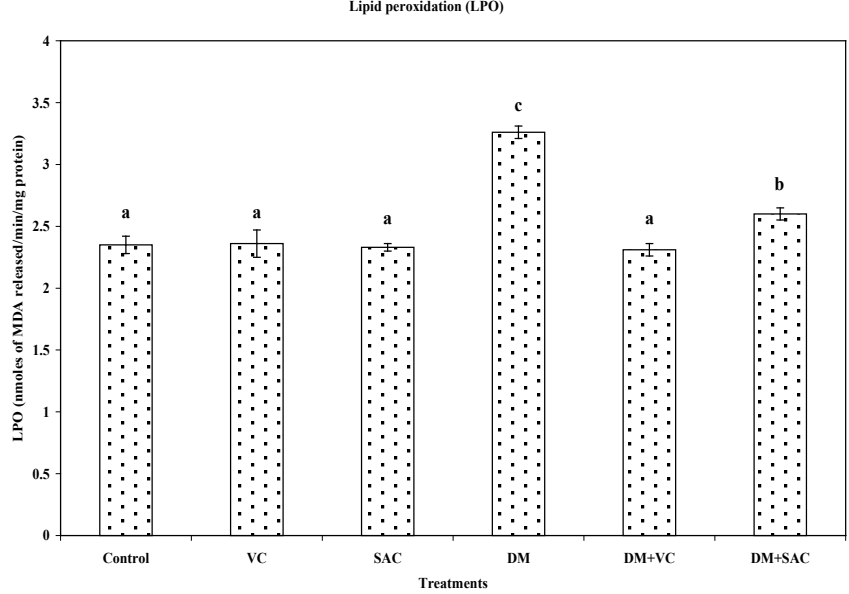

Figure 4: Effect of repetitive doses, for 28 consecutive days, of DM and different antioxidants on LPO in rat liver. Values are expressed as mean $\pm S$. D. of 6 rats; a, b, c, d Values are not sharing superscripts letters $(a, b, c, d)$ differ significantly at $p<0.05$; DM: dimethoate; LPO: lipid peroxidation; VC: vitamin C; SAC: synthetic antioxidant compound.

GSH

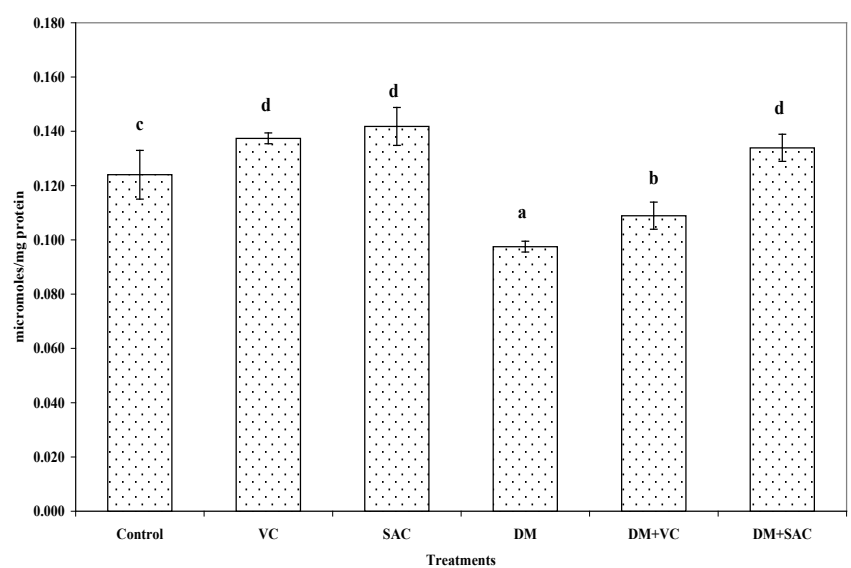

Figure 5: Effect of repetitive doses, for 28 consecutive days, of DM and different antioxidants on GSH content in rat liver. Values are expressed as mean \pm S.D. of 6 rats; a, b, c, d Values are not sharing superscripts letters $(a, b, c, d)$ differ significantly at $p<0.05$; DM: dimethoate; GSH: glutathione; VC: vitamin C; SAC: synthetic antioxidant compound.

increased among DM-treated rats compared to the control group. Supplementation of either VC or SAC to DM-treated group attenuated the statistically significant increases in the activities of both CAT and GST. However, supplementation of SAC induced non significant changes in SOD activity. Furthermore, supplementation of either VC or SAC significantly boosted the antioxidant enzyme activities of SOD and GST, while significantly decreased CAT activity in hepatic tissues (Table 2).

\section{DNA damage results}

Table 3 shows the effects of DM, VC, SAC treatments on damage index (DI) and damage frequency percent (DF), as measured by DNA damage in rat brain tissue, using the comet assay. Compared to the control values for DI (56.0) and DF (28.8), all the treatments except of SAC induced significant elevation $(\mathrm{P}<0.05)$ in the levels of the tested parameters, regardless the repairing and/or the ameliorating effect of both tested antioxidants. It is obvious from the data, that SAC compound was more potent than vitamin $\mathrm{C}$ in mitigating the elevated DNA damage represented by DI and DF values.

Figure 6 shows the extent of DNA damage in brain of rat treated with DM and different antioxidants, analyzed using a SCG assay (grades 0-4). In DM-treated group, the percent of maximum damage cells (grade 4 ) was $25.75 \%$ compared to the untreated group $(3.25 \%$ ). However, supplementations of either VC or SAC changed these values to 7.75 and $8 \%$, respectively. Also, the undamaged cells (grade 0) was $77.75 \%$ in control group, which in turn changed to $28.25 \%$ in DM-treated group, however this percent was modulated to 41.25 and $48.75 \%$, in case of $\mathrm{MD}+\mathrm{VC}$ and $\mathrm{MD}+\mathrm{SAC}$ groups, respectively.

\section{Discussion}

The present study addressed the potential of DM to induce hepatic oxidative stress and whether this oxidative stress can induce brain DNA damage, and to assess the extent of protective effect of either SAC or VC.

In toxicological studies, organ and relative organ weights are important criteria for evaluation of organ toxicity [2,33]. Observation in the present study demonstrates that subacute DM administration produced toxicity in rats as monitored by body weight loss and increase in relative and absolute liver weight. These observations are in accordance with those obtained by previous studies $[11,13,14,34]$. The reduction in body weight gains may be due to the combined action of cholinergic and oxidative stress [19,34-37] and/or due to the increased degradation of lipids and proteins as a direct effect of organophosphate compound exposure [38]. Moreover, the increase in liver weight could be attributed to the relationship between liver weight increase and various toxicological effects or to the reduction in body weight gain of experimental animals [2,34,36,39-41]. However, co-administration with SAC or VC attenuated the statistical different change of body and relative liver weights in DM-treated animals.

Since oxidative stress has been implicated to be an important component of the mechanism of toxicity of several OPI $[42,43]$, the measurements of LPO and GSH content as biomarkers of oxidative stress is crucial. In the current study, DM induced a significant increase

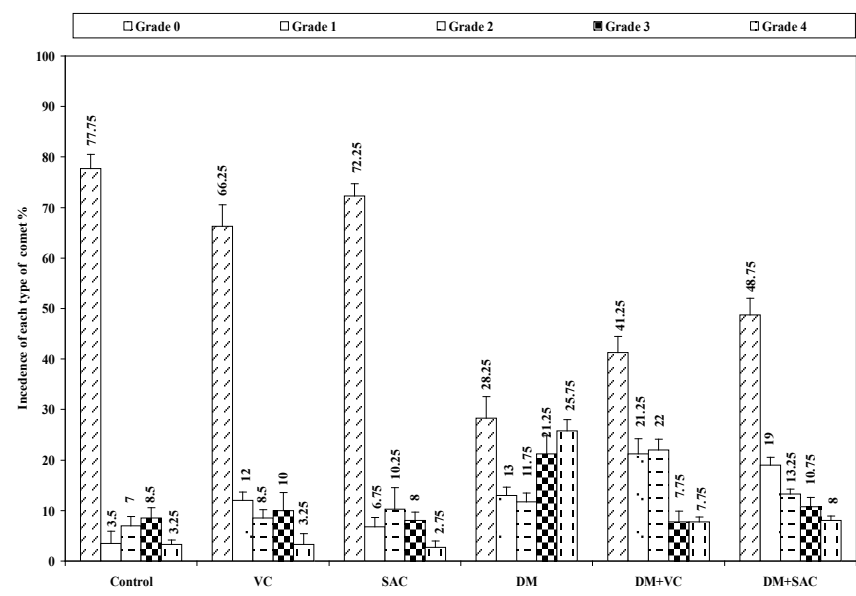

Figure 6: Distribution of damage grades (0-undamaged to 4-maximum damage) in brain of rats treated with DM and different antioxidants for 28 consecutive days. Values are expressed as mean \pm S.D. of 4 rats; DM: dimethoate; VC: vitamin C; SAC: synthetic antioxidant compound. 
Citation: Heikal TM, Mossa ATH, Nawwar GAM, El-Sherbiny M, Ghanem HZ (2012) Protective Effect of a Synthetic Antioxidant "Acetyl Gallate Derivative" Against Dimethoate Induced DNA Damage and Oxidant/Antioxidant Status in Male Rats. J Environ Anal Toxicol 2:155. doi:10.4172/2161-0525.1000155

Page 5 of 7

\begin{tabular}{|l|l|l|l|l|l|}
\hline \multirow{2}{*}{ Groups } & \multicolumn{3}{|c|}{ Body weight } & Absolute liver weight (g) & Relative liver weight (g/100g body weight) \\
\cline { 2 - 6 } & Initial (g) & Final $(\mathbf{g})$ & \% Change & & $3.51 \pm 0.14^{\mathrm{a}}$ \\
\hline G1 (Control) & $159.0 \pm 5.48^{\mathrm{ab}}$ & $213.8 \pm 9.09^{\mathrm{cd}}$ & $34.5 \pm 3.53^{\mathrm{c}}$ & $7.52 \pm 0.51^{\mathrm{a}}$ & $3.64 \pm 0.20^{\mathrm{a}}$ \\
\hline G2 (VC) & $163.8 \pm 4.49^{\mathrm{b}}$ & $216.0 \pm 5.15^{\mathrm{d}}$ & $31.9 \pm 2.74^{\mathrm{bc}}$ & $7.85 \pm 0.41^{\mathrm{a}}$ & $3.66 \pm 0.16^{\mathrm{a}}$ \\
\hline G3 (SAC) & $158.8 \pm 3.03^{\mathrm{ab}}$ & $209.6 \pm 5.27^{\mathrm{bcd}}$ & $32.0 \pm 3.62^{\mathrm{bc}}$ & $7.66 \pm 0.40^{\mathrm{a}}$ & $4.45 \pm 0.20^{\mathrm{c}}$ \\
\hline G4 (DM) & $163.2 \pm 6.06^{\mathrm{b}}$ & $202.2 \pm 8.47^{\mathrm{ab}}$ & $23.9 \pm 1.84^{\mathrm{a}}$ & $8.98 \pm 0.22^{\mathrm{b}}$ & $3.96 \pm 0.15^{\mathrm{b}}$ \\
\hline G5 (DM+VC) & $154.4 \pm 4.83^{\mathrm{a}}$ & $199.4 \pm 7.60^{\mathrm{a}}$ & $29.1 \pm 2.41^{\mathrm{b}}$ & $7.90 \pm 0.14^{\mathrm{a}}$ & $3.68 \pm 0.10^{\mathrm{a}}$ \\
\hline G6 (DM+SAC) & $159.5 \pm 4.25^{\mathrm{ab}}$ & $204.9 \pm 4.18^{\mathrm{abc}}$ & $28.5 \pm 2.04^{\mathrm{b}}$ & $7.54 \pm 0.33^{\mathrm{a}}$ & \\
\hline
\end{tabular}

Each value is a mean of 6 rats $\pm \mathrm{SD} ; \mathrm{a}, \mathrm{b}, \mathrm{c}, \mathrm{d}$ values are not sharing superscripts letters $(\mathrm{a}, \mathrm{b}, \mathrm{c}, \mathrm{d})$ differ significantly at $p<0.05 ; \%$ of body weight change $=[($ final $\mathrm{b} . \mathrm{w} \mathrm{t}$.-initial b.wt.)/initial b.wt.] $\times 100$. DM: Dimethoate; VC: vitamin C; SAC: Synthetic antioxidant compound

Table 1: Body weight, liver weight, and relative liver weight of control and experimental rats.

\begin{tabular}{|c|c|c|c|}
\hline Groups & $\begin{array}{l}\text { Catalase (CAT) (nmoles/min/mg } \\
\text { protein) }\end{array}$ & Superoxide dismutase (SOD) ( $\mu$ /mg Protein) & $\begin{array}{l}\text { Glutathione-S-Transferase (GST) } \\
\text { ( } \mu \mathrm{moles} / \mathrm{min} / \mathrm{mg} \text { protein) }\end{array}$ \\
\hline G1 (Control) & $344.5 \pm 11.6^{b}$ & $10.39 \pm 0.70^{\mathrm{a}}$ & $0.051 \pm 0.005^{b}$ \\
\hline G2 (VC) & $322.4 \pm 11.7^{\mathrm{a}}$ & $12.70 \pm 1.23^{b}$ & $0.061 \pm 0.004^{c}$ \\
\hline G3 (SAC) & $313.4 \pm 8.9^{a}$ & $12.92 \pm 0.89^{b}$ & $0.059 \pm 0.003^{c}$ \\
\hline G4 (DM) & $410.7 \pm 19.7^{d}$ & $17.42 \pm 0.97^{c}$ & $0.078 \pm 0.004^{d}$ \\
\hline G5 (DM+VC) & $382.6 \pm 11.8^{c}$ & $11.94 \pm 0.72^{b}$ & $0.058 \pm 0.005^{c}$ \\
\hline G6 (DM+SAC) & $371.6 \pm 11.3^{c}$ & $11.63 \pm 1.67^{\mathrm{ab}}$ & $0.042 \pm 0.005^{\mathrm{a}}$ \\
\hline
\end{tabular}

Each value is a mean of 6 rats $\pm \mathrm{SD}$; a, b, c, d values are not sharing superscripts letters $(a, b, c, d)$ differ significantly at $p<0.05$; DM: Dimethoate; VC: vitamin C; SAC: Synthetic antioxidant compound

Table 2: Effect of VC and SAC on hepatic antioxidant enzymes of control and experimental rats.

\begin{tabular}{|l|l|l|}
\hline Groups & Damage index (DI) & Damage frequency \% (DF) \\
\hline G1 (Control) & $56.0 \pm 5.94^{\mathrm{a}}$ & $28.8 \pm 4.51^{\mathrm{a}}$ \\
\hline G2 (VC) & $72.0 \pm 6.97^{\mathrm{b}}$ & $51.2 \pm 7.34^{\mathrm{a}}$ \\
\hline G3 (SAC) & $62.2 \pm 9.11^{\mathrm{ab}}$ & $38.7 \pm 6.13^{\mathrm{a}}$ \\
\hline G4 (DM) & $203.3 \pm 15.19^{\mathrm{d}}$ & $260.4 \pm 56.76^{\mathrm{d}}$ \\
\hline G5 (DM+VC) & $119.5 \pm 4.51^{\mathrm{c}}$ & $143.1 \pm 15.04^{\mathrm{c}}$ \\
\hline G6 (DM+SAC) & $109.7 \pm 9.14^{\mathrm{c}}$ & $106.1 \pm 16.27^{\mathrm{b}}$ \\
\hline
\end{tabular}

Each value is a mean of 4 rats $\pm S D ; a, b, c, d$ values are not sharing superscripts letters $(a, b, c, d)$ differ significantly at $p<0.05$; Damage index (DI) $=$ cells number of each class $\times$ number of classes (O-4), maximum value $=400$ arbitrary unit); Damage frequency $\%(D F)=$ (number of cells with tail/ number of cells without tail) $\times 100$; DM: Dimethoate; VC: vitamin C; SAC: Synthetic antioxidant compound

Table 3: Effect of VC and SAC on brain DNA damage of control and experimental rats.

in the levels of MDA accompanied by a significant decrease in GSH content in liver tissues. Our results are in agreement with similar data reported in different experimental models of rats exposed to dimethoate and other pesticides $[11,13,37,40,42-44]$. In fact, DM is a lipophilic substance and therefore it can interact with cellular liver membrane. MDA is a major oxidation product of peroxidized polyunsaturated fatty acids and its increase is an important indicator of lipid peroxidation [45]. Lipid peroxidation explain a number of deleterious effects such as increased membrane rigidity, osmotic fragility, decreased cellular deformation, reduced erythrocyte survival, and membrane fluidity [46]. So, the increase in lipid peroxidation leads to tissue injury and failure of the antioxidant defense mechanisms to prevent the formation of excess free radicals [47]. GSH can act either to detoxify ROS such as $\mathrm{H}_{2} \mathrm{O}_{2}$ or to reduce lipid peroxides themselves [48]. Depletion of GSH as observed in our results in DM-treated group reflects its potential for detoxification.

Free radicals are highly reactive and potentially damaging transient chemical species. Cellular injury is primarily due to inability of antioxidant to neutralize the effects of these radicals $[2,40,42,43,49]$. The protective action of antioxidant may be due to an inhibition of reactive oxygen species (ROS) inducing a chain reaction mediated by several antioxidant enzymes including SOD, GST and catalase. In our model, the significant increase in the hepatic activities of the antioxidant enzymes CAT and SOD after DM treatment may be due to an adaptive response to the generated free radicals [50] or may indicate an activation of the compensatory mechanism through the effect of DM on progenitor cells, and its extent depends on the magnitude of the oxidative stress and hence on the dose of stressor. Also, GST was significantly increased in DM-treated rats. GST are detoxifying enzymes that catalyze the conjugation of variety of electrophilic substrate to the thiol group of GSH, producing less toxic forms [51]. The increase in GST activity in the liver tissue among DM treated rats indicates the role played by this system in the detoxification of DM. Our results are consistent with previous researchers after DM and other insecticides administration to rats $[11,14,17,40,52]$. In contrast, other investigators reported reduction in the activities of antioxidant enzymes and they attributed this reduction to the inability of the organism to counteract the high production of ROS resulting from a high dose of DM [53]. From the other hand, co-administration of either VC or SAC showed a varying potent effect against oxidative stress and lipid peroxidation. Also, it is remarkable that SAC was more effective than $\mathrm{VC}$ in attenuating hepatic SOD activity.

Apart of lipid peroxidation and glutathione content, another major question addressed was whether DM induced DNA damage is mediated through oxidative stress. In the present study, DM treatment induced brain DNA damage evidenced by comet assay, which is a rapid, simple and sensitive technique for measuring and analyzing DNA breakage in separated cells [32]. The types of DNA damage produced by radiation 
Citation: Heikal TM, Mossa ATH, Nawwar GAM, El-Sherbiny M, Ghanem HZ (2012) Protective Effect of a Synthetic Antioxidant "Acetyl Gallate Derivative" Against Dimethoate Induced DNA Damage and Oxidant/Antioxidant Status in Male Rats. J Environ Anal Toxicol 2:155. doi:10.4172/2161-0525.1000155

Page 6 of 7

and/or chemicals are many and varied, including single- and doublestrand breaks. The single cell gel electrophoreses test (SCG), or comet assay, adopted in our study is a rather new test with a widespread potential applications in genotoxicity testing and biomonitoring $[30,51]$.

The increase of DNA damage in our result is consistent with previous investigators [17], who reported same result with chlorpyrifos. It is well documented that xenobiotic chemicals, including OPI, induce oxidative stress $[42,43]$, which in turn leads to DNA damage recorded in our study. ROS left unbalanced by antioxidants (enzymatic) can result in damage to cellular macromolecules. In DNA, ROS can produce single- double strand DNA breaks, purine, pyrimidine, or deoxyribose modifications and DNA crosslink [54,55].

Antioxidants are believed to be directly antimutagenic and anticarcinogenic due to their radical scavenging properties [56-59]. Compounds showing antioxidant activity can reduce the main load of oxidative stress but when there is an imbalance between oxidizing and reducing equivalents where the former predominates, for example when the antioxidant is oxidized and thus converted into a prooxidant, the antioxidant cellular defenses cannot fully keep up with the oxidative stress and important cellular constituents are damaged [60]. In our model, the supplementation of the two tested antioxidants resulted in attenuation of oxidative stress and consequently reduction in DNA damage, especially with the SAC compound.

The role of vitamin $\mathrm{C}$ as antioxidant in biological systems is well known and can be summarized as scavenging free radical [59], restoring vitamin $\mathrm{E}$ [61], neutralizing the reactive oxygen metabolites, and reducing DNA damage and hence genetic mutation. In contrast, the supplementation of SAC is more reliable than $\mathrm{VC}$ in attenuating relative liver weight, SOD, GST, and brain DNA damage in DMtreated animals. The antioxidant activity of SAC has been attributed to various mechanisms, among which is the binding of transition metal ion. In this respect, it seems that the tri-hydroxyl system in galloyl moiety plays a decisive role. Also, the presence of carbonyl, active methylen, and nitrile groups in SAC afford a wide range of biological activities, which could extend its free radicals scavenging and terminate lipid peroxidation. However, further investigations are suggested to elucidate the precise protective mechanism of SAC against DNA damage and oxidative stress in mammals.

In conclusion, the present study demonstrates the capacity of VC and SAC to attenuate the hepatotoxicity and brain DNA damage in rat after subacute exposure to DM. It is also clear that SAC is more reliable than VC in attenuating relative liver weight, SOD, GST, and brain DNA damage in DM-treated animals. However, the accurate mechanism of SAC as antioxidant is not yet clear. So, further studies are warranted before SAC can be considered as a new synthetic antioxidant compound.

\section{Acknowledgement}

The authors are thankful to STDF which provided the financial support for the project ID 133

\section{References}

1. Hazarika A, Sarkar SN, Hajare S, Kataria M, et al. (2003) Influence of malathion pretreatment on the toxicity of anilofos in male rats: a biochemical interaction study. Toxicology 185: 1-8.

2. Heikal TM, Ghanem HZ, Soliman MS (2011) Protective effect of green tea extracts against dimethoate induced DNA damage and oxidant/antioxidant status in male rats. Biohealth Science Bulletin 3: 1-11.

3. Mansour SA, Barakat AA, Mahafrash SM, Heikal TM, El Mahy SA (2012)
Ameliorative effect of selenium on the hepatotoxicity of methomyl, some common drugs and their combinations. ScienceJet 1:18.

4. Samanta L, Chainy GB (1995) Hexachlorocyclohexane-induced changes in lipid peroxidation, superoxide dismutase and catalase activities and glutathione content in chick liver. Indian J Exp Biol 33: 131-133.

5. Lemaire P, Mathews A, Forlin L, Livingstone DR (1994) Stimulation of oxyradical production of hepatic microsomes of flounder (Platichthys flesus) and perch (Perca fluviatilis) by model and pollutant xenobiotics.Arch Environ Contam Toxicol 26: 191-200.

6. Akhgari $M$, Abdollahi $M$, Kebryaeezadeh A, Hosseini R, Sabzevari O (2003) Biochemical evidence for free radical-induced lipid peroxidation as a mechanism for subchronic toxicity of malathion in blood and liver of rats. Hum Exp Toxicol 22: 205-211.

7. Gultekin F, Ozturk M, Akdogan M (2000) The effect of organophosphate insecticide chlorpyrifos-ethyl on lipid peroxidation and antioxidant enzymes (in vitro). Arch Toxicol 74: 533-538.

8. Gupta RC, Milatovic D, Dettbarn WD (2001) Depletion of energy metabolites following acetylcholinesterase inhibitor-induced status epilepticus: protection by antioxidants. Neurotoxicology 22: 271-282.

9. Ranjbar A, Pasalar P, Abdollahi M (2002) Induction of oxidative stress and acetylcholinesterase inhibition in organophosphorus pesticide manufacturing workers. Hum Exp Toxicol 21: 179-182.

10. WHO/IPCS (1996) Principles and methods for assessing direct immunotoxicity associated with exposure to chemicals. Environmental Health Criteria 180 110-112.

11. Sivapiriya V, Jayanthisakthisekaran J, Venkatraman S (2006) Effects of dimethoate (O,O-dimethyl S-methyl carbamoyl methyl phophorodithioate) and ethanol in antioxidant status of liver and kidney of experimental mice. Pest Biochem Physiol 85: 115-121.

12. Kamath V, Joshi AKR, Rajini PS (2008) Dimethoate induced biochemica perturbations in rat pancreas and its attenuation by cashew nut skin extract. Pest Biochem Physiol 90: 58-65.

13. Sayim F (2007) Histopathological effects of dimethoate on testes of rats. Bull Environ Contam Toxicol 78: 479-484

14. Sharma Y, Bashir S, Irshad M, Nag TC, Dogra TD (2005) Dimethoate-induced effects on antioxidant status of liver and brain of rats following subchronic exposure. Toxicology 215: 173-181.

15. Verma RS, Mehta A, Srivastava N (2007) In vivo chlorpyrifos induced oxidative stress: attenuation by antioxidant vitamins. Pest Biochem Physiol 88: 191-196.

16. Adali M, Inal-Erden M, Akalin A, Efe B (1999) Effects of propothiourcil, propranolol and vitamin $\mathrm{E}$ on lipid peroxidation and antioxidant status in hyperthyroid patients. Clin Biochem 21: 363-367.

17. Yu F, Wang Z, Ju B, Wang Y, Wang J, et al. (2008) Apoptotic effect of organophosphorus insecticide chlorpyrifos on mouse retina in vivo via oxidative stress and protection of combination of vitamin C and E. Exp Toxicol Patho 59: 415-423.

18. El-Ebiary NM, Swellem RH, Mossa AT, Nawwar GA (2010) Synthesis and antioxidant activity of new pyridines containing the gallate moieties. Arch Pharm (Weinheim) 9: 528-534.

19. Tomlin CDS (2009) The Pesticide Manual: A World compendium (15thedn). British Crop Production Council, London, UK.

20. Dirican EK, Kalender $Y$ (2011) Dichlorvos-induced testicular toxicity in male rats and the protective role of vitamins $\mathrm{C}$ and $\mathrm{E}$. Exp Toxicol Pathol.

21. Ogutcu A, Suludere Z, Kalender Y (2008) Dichlorvos-induced hepatotoxicity in rats and the protective effects of vitamins $\mathrm{C}$ and $\mathrm{E}$. Environ Toxicol Pharmacol 26: $355-361$.

22. Kamath V, Rajini PS (2007) Altered glucose homeostasis and oxidative impairment in pancreas of rats subjected to dimethoate intoxication. Toxicology 231: $137-146$

23. Ohkawa H, Ohishi N, Yagi K (1979) Assay for lipid peroxides in animal tissues by thiobarbituric acid reaction. Anal Biochem 95: 351-358.

24. Owens CW, Belcher RV (1965) A colorimetric micro-method for the determination of glutathione. Biochem J 94: 705-711. 
Citation: Heikal TM, Mossa ATH, Nawwar GAM, El-Sherbiny M, Ghanem HZ (2012) Protective Effect of a Synthetic Antioxidant "Acetyl Gallate Derivative" Against Dimethoate Induced DNA Damage and Oxidant/Antioxidant Status in Male Rats. J Environ Anal Toxicol 2:155. doi:10.4172/2161-0525.1000155

25. Aebi H (1984) Catalase in vitro. In Methods in Enzymology, ed. S.P. Colowick and N.O. Kaplan 105: 121-126. New York: Academic Press

26. Nishikimi M, Appaji N, Yagi K (1972) The occurrence of superoxide anion in the reaction of reduced phenazine methosulfate and molecular oxygen. Biochem Biophys Res Commun 46: 849-854

27. Habig WH, Pabst MJ, Jakoby WB (1974) Glutathione S-transferases. The firs enzymatic step in mercapturic acid formation. J Biol Chem 249: 7130-7139.

28. Lowry OH, Rosebrough NJ, Farr AL, Randall RJ (1951) Protein measurement with the Folin phenol reagent. J Biol Chem 193: 265-275.

29. Ellman GL, Counrtney KD, Andres V Jr, Feather-Stone RM (1961) A new and rapid colorimetinc determination of acetylcholinesterase activity. Biochem Pharmacol 88-95.

30. Singh NP, McCoy MT, Tice RR, Schneider EL (1988) A simple technique for quantitation of low levels of DNA damage in individual cells. Exp Cell Res 175 184-191.

31. Tice RR, Agurell E, Anderson D, Burlinson B, Hartmann A, et al. (2000) Single cell gel/comet assay: guidelines for in vitro and in vivo genetic toxicology testing. Environ Mol Mutagen 35: 206-221.

32. Collins AR, Ai-guo M, Duthie SJ (1995) The kinetics of repair of oxidative DNA damage (strand breaks and oxidized pyrimidines) in human cells. Mutat Res 336: 69-77.

33. Crissman JW, Goodman DG, Hildebrandt PK, Maronpot RR, Prater DA, et al (2004) Best practice guideline: Toxicol Pathol 32: 126-131.

34. Saafi EB, Louedi M, Elfeki A, Zakhama A, Najjar MF, et al. (2011) Protective effect of date palm fruit extract (Phoenix dactylifera L.) on dimethoate inducedoxidative stress in rat liver. Exp Toxicol Pathol 63: 433-441.

35. Grance SR, Teixeira MA, Leite RS, Guimarães EB, de Siqueira JM, et al. (2008) Baccharis trimera: effect on hematological and biochemical parameters and hepatorenal evaluation in pregnant rats. J Ethnopharmacol 117: 28-33.

36. Mansour SA, Heikal TM, Refaie AA, Mossa AH (2011) Antihepatotoxic activity of fennel (Foeniculum vulgare Mill.) essential oil against chlorpyrifos-induced liver injury in rats. Global J Environ Sci Technol 1:1-10.

37. Heikal TM, Mossa ATH, Marei GIK, Abdel Rasoul MA (2012) Cyromazine and chlorpyrifos induced renal toxicity in rats: The Ameliorating effects of green tea extract. J Environ Anal Toxicol doi.org/10.4172/2161-0525.1000146.

38. Hagar HH, Azza H, Fahmy (2002) A biochemical, histochemical and ultrastructural evaluation of the effect of dimethoate intoxication on rat pancreas. Toxicol Lett 133: 161-170.

39. Amacher DE, Schomaker SJ, Burkhardt JE (1998) The relationship among microsomal enzyme induction, liver weight and histological change in rat toxicology studies. Food Chem Toxicol 36: 831-839.

40. Heikal TM, Soliman MS (2010) Effect of fish oil supplementation on brain DNA damage and hepatic oxidant/antioxidant status in dimethoate-treated rats. J Egypt Soc Toxicol 42: 1-9.

41. Mahjoubi-Samet A, Fetoui $H$, Zeghal N (2008) Nephrotoxicity induced by dimethoate in adult rats and their suckling pups. Pest Biochem Physiol 91: 96-103.

42. Bagchi D, Bagchi M, Hassoun EA, Stohs SJ (1995) In vitro and in vivo generation of reactive oxygen species, DNA damage and lactate dehydrogenase leakage by selected pesticides. Toxicology 104:129-140.

43. Ogutcu A, Uzunhisarcikli M, Kalender S, Durak D, Bayrakdar F, et al. (2006) The effect of organophosphate insecticide diazinon on malaondialdehyde levels and myocardial cells in rat heart tissue and protective role of Vitamin $E$. Pest Biochem Physiol 86: 93-98.

44. Srivastava MK, Raizada RB (1996) Developmental effect of technical dimethoate in rats: maternal and fetal toxicity evaluation. Indian J Exp Biol 34: 329-333.

45. Freeman BA, Crapo JD (1981) Hyperoxia increases oxygen radical production in rat lungs and lung mitochondria. J Biol Chem 256: 10986-10992.

46. Thampi BS, Manoj G, Leelamma S, Menon VP (1991) Dietary fiber and lipid peroxidation: effect of dietary fiber on levels of lipids and lipid peroxides in high fat diet. Indian J Exp Biol 29: 563-567.

47. Comporti M (1985) Lipid peroxidation and cellular damage in toxic liver injury. Lab Invest 53: 599-623.
48. Freeman BA, Crapo JD (1982) Biology of disease: free radicals and tissue injury. Lab Invest 47: 412-426.

49. Saulsbury MD, Heyliger SO, Wang K, Johnson DJ (2009) Chlorpyrifos induces oxidative stress in oligodendrocyte progenitor cells. Toxicology 259: 1-9.

50. Koner BC, Banerjee BD, Ray A (1997) Modulation of gamma glutamy transpeptidase activity in lymphoid system by organochlorine pesticides in rats. Indian J Exp Biol 35: 1132-1134.

51. Hayes JD, Pulford D (1995) The glutathione-S-transferase supergene family: regulation of GST and the contribution of the isoenzymes to cancer chemoprotection and drug resistance. Crit Rev Biochem Mol Biol 30: 445-600.

52. Oncu M, Gultekin F, Karaoz E, Altuntas I, Delibas N (2002) Nephrotoxicity in rats induced by chlorpyrifos-ethyl and ameliorating effects of antioxidants. Hum Exp Toxicol 21: 223-230.

53. Mahboob M, Siddiqui MK (2001) Alterations in hepatic detoxifying enzymes induced by new organophosphorus insecticides following subchronic exposure in rats. J Appl Toxicol 21: 501-505.

54. Demple B, Harrison L (1994) Repair of oxidative damage to DNA: enzymology and biology. Annu Rev Biochem 63: 915-948.

55. Dizdaroglu M (1992) Oxidative damage to DNA in mammalian chromatin. Muta Res 275: 331-342.

56. Clark SF (2002) The biochemistry of antioxidants revisited. Nutr Clin Pract 2 5-17.

57. Surh YJ (2002) Anti-tumor promoting potential of selected spice ingredients with antioxidative and anti-inflammatory activities: a short review. Food Chem Toxicol 40: 1091-1097.

58. Collins AR (2005) Antioxidant intervention as a route to cancer prevention. Eu J Cancer 41: 1923-1930.

59. Sies H, Cadenas E (1985) Oxidative stress: damage to intact cells and organs Philos Trans R Soc Lond B Biol Sci. 311: 617-631.

60. Serbecic N, Beutelspacher SC (2005) Anti-oxidative vitamins prevent lipid peroxidation and apoptosis in corneal endothelial cells. Cell Tissue Res 320 465-475.

61. Frei B (1994). Reactive oxygen species and antioxidant vitamins: Mechanism of action. Am J of Med 97: S5-S13. 